\title{
A MOOC TAXONOMY BASED ON CLASSIFICATION SCHEMES OF MOOCS
}

Tharindu R.Liyanagunawardena [tharindu@ucem.ac.uk], University College of Estate Management [https:/ / www.ucem.ac.uk], Horizons, 60 Queen's Road, Reading RG1 4BS, United Kingdom, Karsten Lundqvist [karsten.lundqvist@vuw.ac.n₹], Victoria University of Wellington [bttps:/ / wmw.victoria.ac.n₹], Kelburn Campus, PO Box 600, Wellington 6140, New Zealand, Richard Mitchell [r.j.mitchell@reading.ac.uk], University of Reading [http:/ / www.reading.ac.uk], Department of Computer Science University of Reading, Polly Vacher Building, Whiteknights, Reading RG6 6AY, United Kingdom, 850, StevenWarburton [steven.warburton@vuw.ac.nz],Victoria University of Wellington [https:// mmw.victoria.ac.ñ], Kelburn Campus, PO Box 600, Wellington 6140, New Zealand, Shirley A. Williams [Shirley.williams@reading.ac.uk],Department of Computer Science, University of Reading, Polly Vacher Building, Whiteknights, Reading RG6 6AY, United Kingdom

\begin{abstract}
In recent years there has been a significant growth in the number of online courses known as MOOCs available via online providers such as edX and Coursera. The result has been a marked reduction in the clarity around the different course offerings and this has created a need to reconsider the classification schemes for MOOCs to help inform potential participants. Many classifications have been proposed which cover the needs of academics and providers but may not be suitable for learners choosing a course. In this paper, the various classifications used by MOOC providers and aggregator services to categorise MOOCs in presenting information to prospective learners are gathered and analysed. As a result, 13 different categories are identified, which cover information provided to learners before entering a course. These categories are then compared and combined with classifications from the literature to create a taxonomy centred round eight terms: Massive (e.g. enrolments), Open (e.g. pre-requisites), Online (e.g. Timings), Assessment, Pedagogy (e.g. instructor-led), Quality (e.g. reviews), Delivery (e.g. educators), Subject (e.g. Syllabus). Thus, producing a taxonomy capable of categorising MOOCs from a wider perspective.
\end{abstract}

\section{Abstract in Greek}

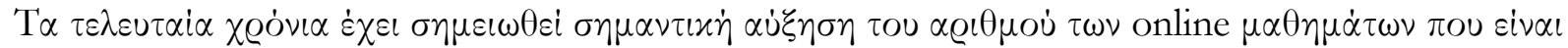

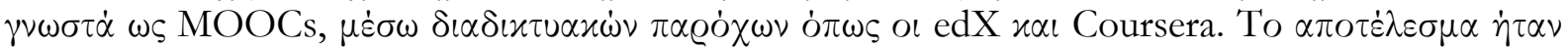

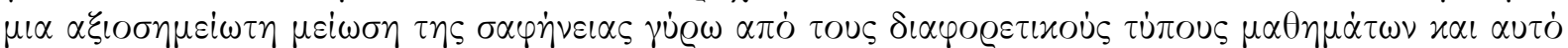

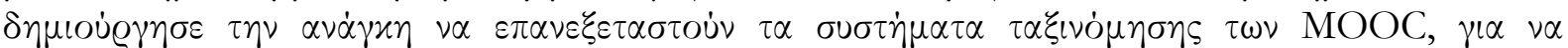

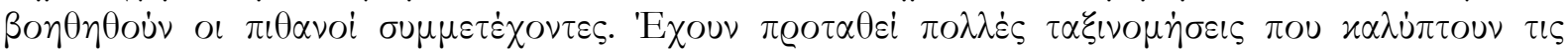

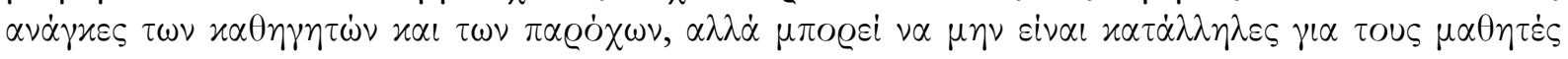

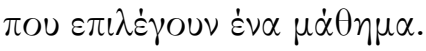

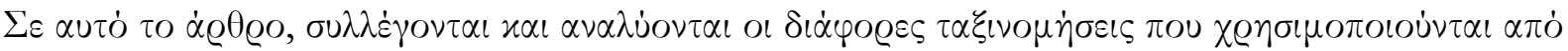

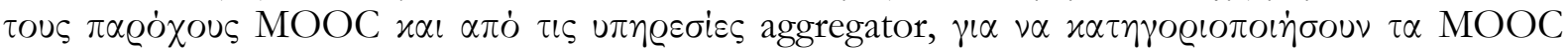

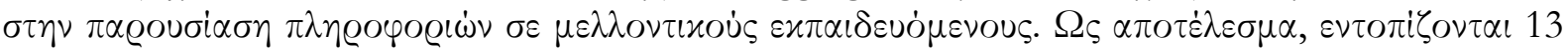

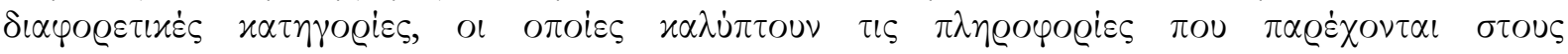

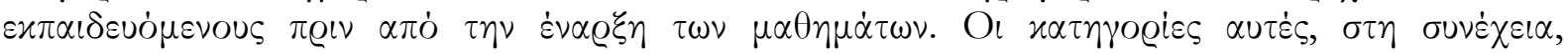

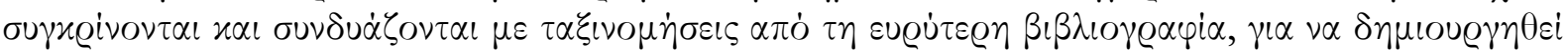

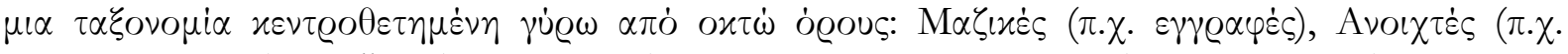

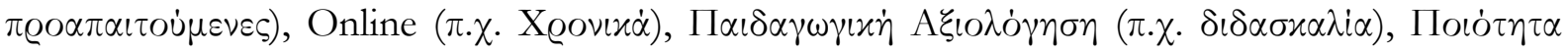




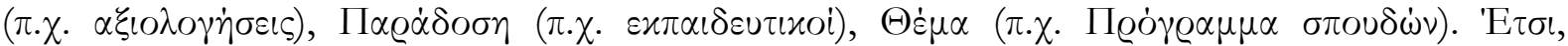

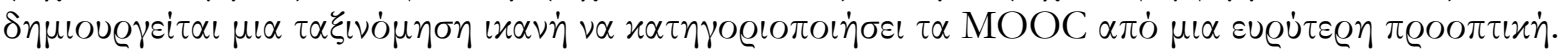

\section{Abstract in Danish}

I de sidste år har der været en stor stigning i antallet af internet kurser, kendt som MOOCs, givet igennem servicer såsom edX og Coursera. Dette har resulteret $\mathrm{i}$ en reduceret klarhed for potentielle studerende, og der er et behov for at reevaluere MOOC klassifikationer så potentielle studerende kan blive bedre informeret. Der findes mange klassifikationer som opfylder behovene for akademikere og kursus udbydere, men det kan være disse ikke opfylder behovene for studerende mens de vælger et kursus. Denne artikel identificerer 13 forskellige kategorier, som dækker information der bliver givet til studerende før de starter et kursus af kursus udbydere. Disse kategorier bliver sammenlignet og slået sammen med klassifikationerne fundet i litteraturen og herved opstå en ny taksonomi centreret omkring otte koncepter: Mængde (f.eks. antal tilmeldinger), Ảbenhed (f.eks. forudsætninger for at starte kurset), Online (f.eks. timing af kursus), Evaluering, Pædagogik (f.eks. ledt af instruktører), Kvalitet (f.eks. anmeldelser af tidligere studerende), Levering (f.eks. underviserer), Tema (f.eks. syllabus). Herved udarbejdes en taksonomi som kan bruges til at kategoriserer MOOCs fra et videre perspektiv end før.

\section{Abstract in Portuguese (Brazilian)}

Nos últimos anos, houve um crescimento significativo no número de cursos online conhecidos como MOOCs disponíveis por meio de provedores online, como o edX e o Coursera. O resultado foi uma redução acentuada na clareza em torno das diferentes ofertas de cursos. Isso criou a necessidade de reconsiderar como esses cursos são classificados para ajudar a informar os possíveis participantes. Muitas classificações foram propostas que cobrem as necessidades de acadêmicos e provedores, mas podem não ser adequadas para os alunos que escolhem um curso. Neste artigo, reunimos e analisamos as várias classificações usadas pelos provedores de MOOC e os serviços agregadores para categorizar os MOOCs na apresentação de informações aos alunos em potencial. Como resultado, são identificadas 13 categorias diferentes, que abrangem as informações fornecidas aos alunos antes de ingressar em um curso. Essas categorias são comparadas e combinadas com classificações da literatura para criar uma taxonomia centrada em oito termos: Massivo (por exemplo, inscrições), Aberto (por exemplo, pré-requisitos), Online (por exemplo, horários), Avaliação, Pedagogia (por exemplo, com instrutor) Qualidade (por exemplo, inspecionado), Entrega (por exemplo, educadores), Assunto (por exemplo, curriculo). Produzindo assim uma taxonomia capaz de categorizar os MOOCs de uma perspectiva mais ampla.

Keywords: MOOC, taxonomy, classification

\section{Introduction}

The continuing maturity of online learning is one of the major educational advancements of the $21^{\text {st }}$ century. Massive Open Online Courses (MOOCs) represent one of the most recent evolutions within this domain, in which courses from a range of institutions, including elite universities, are made open and freely accessible to the world. These courses are designed to engage large numbers of participants who commonly self-organise their involvement according to their skills, objectives, previous knowledge and shared interests.

Since 2012 there has been a huge growth in the number of MOOCs worldwide, stimulated largely by the emergence of the popular MOOC platforms edX, Coursera, Udacity and FutureLearn (Yuan \& Powell, 2013). The courses themselves are developed by institutions, organisations and individuals, and cover a broad range of disciplines and levels. There are many MOOC providers 
and several aggregator services that bring together courses from several providers in one place. This gives prospective participants the ability to find courses offered by providers in one place with several search options to find courses via the various categories generated by these aggregator services.

Traditionally prospective students would select courses based on paper brochures (prospectuses). Prospective MOOC learners similarly would rely on provided course descriptions to make their choices. In both cases the prospective learners are making the course choice based on information provided to them. In this study, authors are examining the information provided, in the English language, to the prospective learners prior to committing to the course, for example, if reviews from previous students are available this may influence choice.

As MOOCs have grown in popularity, several classification schemes have been proposed in the literature (Clark, 2013; Conole, 2015; Daniel, 2012; Mohamed \& Hammond, 2017; Pilli \& Admiraal, 2016; Rodriguez, 2012). However, it is not clear if these correspond with the categories of the MOOC providers and aggregator services or if these different categorisations serve the same purposes. Also, whether information (about a MOOC) relating to these categories are made available to a learner, prior to committing to take the course is not known. Therefore, in this paper, the authors review MOOC descriptions made available to prospective learners to explore these issues.

The aim of this paper is threefold. First to review the literature describing existing classification schemes for MOOCs. Second to conduct an analysis of the course descriptions used by MOOC providers and aggregation services to their prospective learners. Third, from this analysis, to evolve a series of categories that describe MOOCs and use this to develop a new taxonomy of MOOCs based on existing classifications and their contemporary use.

The next section comprises a literature review of MOOCs, MOOC classification systems, MOOC providers, and aggregator services for MOOCs. This is followed by a methodology section which describes how providers and aggregator services have been selected for this study and how the data has been selected. The paper then describes the initial investigation and analysis of MOOC providers and aggregator services, which resulted in 13 observable categories. These are discussed in relation to the literature in this domain, and then the 13 categories are merged with the existing literature into a new classification scheme.

\section{Literature Review}

\section{MoOCs}

The term MOOC was coined in 2008 by Cormier (2008) to describe the mode of delivery of a course: CCK08 - Connectivism \& Connective Knowledge (Downes, 2008). Since then, the nature and impact of MOOCs has been widely studied in the academic literature (Liyanagunawardena, Adams, \& Williams, 2013; Ebben \& Murphy, 2014) and beyond (Bozkurt, Keskin, \& de Waard, 2016; Jordan, 2015). Daniel (2012) identified the term MOOC as "the educational buzzword of 2012".

The majority of MOOCs are developed by academic institutions and presented to the public via a MOOC provider platform, for example Cousera, edX and Udacity. Hollands and Tirthali (2014) describe MOOCs as online courses that: "allow hundreds of thousands of students to participate simultaneously in a course and are free and open to any interested participant ..." (p.18). They have now evolved to include paid-for pathways, and this aspect is discussed later in this paper. 
One of the many areas of research interest has been exploration of the motivation for participation (Liyanagunawardena, Lundqvist, \& Williams, 2015a) often focusing on rates of completion. Jordan (2014) in her detailed study of MOOCs found that: " $t$ ] he average MOOC course is found to enrol around 43,000 students, 6.5\% of whom complete the course" (p.133). However, a study by Ferguson and Clow (2015) identified clusters of behaviour that they categorised as seven distinct patterns of engagement: "Samplers; Strong Starters; Returners; Midway Dropouts; Nearly There; Late Completers; and Keen Completers" (p.51). They noted that only the "late completers" and "keen completers" participant categories are included in completion statistics at the end of a course.

The first MOOCs started as open courses, providing both the course materials and a certificate of completion free of charge. Over time there has been an increasing shift towards monetising course offerings, and MOOC providers are coming up with innovative ways to introduce paidfor services and products (Liyanagunawardena, Lundqvist, \& Williams, 2015b). A JISC report by Yuan and Powell (2013) identified that charging a fee for a certificate was the most common revenue stream for the major new MOOC providers.

Most platforms offer course auditing for free and only charge for certification, while some platforms have courses in their catalogues that can only be accessed after paid-for registration; for example on the FutureLearn platform there are paid-for only courses listed that reside among the free online courses, such as "Writing Better Emails" offered by the British Council (https://www.futurelearn.com/courses/better-emails); continuing access to courses one has already taken is often a paid for service.

\section{MOOC Classifications}

A review of MOOC literature by Liyanagunawardena et al. (2013) identified that at the time of writing, MOOCs were being classified according to the pedagogic perspective into two categories with two authors using different terms for essentially the same grouping; Rodriguez (2012) used the two categories: connectivist MOOCs (c-MOOCs) and AI-Stanford like courses, while Daniel (2012) used the terms cMOOCs and xMOOC. In subsequent work, Conole (2014) provided a more detailed definition for these terms:

- xMOOCs: "primarily based around interaction with content and essentially adopting a behaviourist learning approach" (p.65);

- cMOOCs: "which focus on harnessing the power of social media and interaction with peers, adopting a connectivist learning approach" (p.65).

This has been a useful, although simple, classification based on the underlying pedagogy of MOOCs. With the largescale growth in the number of available MOOCs, several alternative classifications have been suggested to provide a more granular understanding of a now more diversified MOOC landscape.

Clark (2013) presented a taxonomy of MOOCs from a pedagogical perspective, focusing on delivery methods of the MOOC. Eight categories were described:

1. Transfer: where an existing course is moved to a platform to be offered as a MOOC;

2. Made: courses which are made specifically to be offered as a MOOC;

3. Synch: courses with a fixed start and duration;

4. Asynch: courses not having a fixed start and end, and material remaining available;

5. Adaptive: courses using adaptive algorithms to offer personalised learning experiences;

6. Group: courses in which small groups of students work together; 
7. Connectivist: in which there is an emphasis on individuals and groups following to contribute to the running and direction of the learning experience, rather than following a strict syllabus;

8. Mini: short courses lasting for less time than the traditional MOOC.

It is worth noting that a single MOOC may fit in to more than one of these categories, for instance a "Transfer MOOC" could also be "Asynch" or "Synch".

After a study focusing on learner engagement and MOOC quality, Conole (2014) concluded:

"... that a better classification of MOOCs is in terms of a set of twelve dimensions: the degree of openness, the scale of participation (massification), the amount of use of multimedia, the amount of communication, the extent to which collaboration is included, the type of learner pathway (from learner centred to teacher-centred and highly structured), the level of quality assurance, the extent to which reflection is encouraged, the level of assessment, how informal or formal it is, autonomy, and diversity" (p.72).

These were condensed into the following twelve dimensions:

1. Open;

2. Massive;

3. Use of multimedia;

4. Degree of communication;

5. Degree of collaboration;

6. Learning pathway;

7. Quality Assurance;

8. Amount of reflection;

9. Certification;

10. Formal learning;

11. Autonomy;

12. Diversity.

To illustrate the efficacy of her classification system, Conole (2014) used a study sample comprising five MOOCs that ran during the period spanning 2011 to 2013. She illustrated goodness of fit by evaluating the degree (low, medium or high) to which the MOOCs fulfilled each dimension. The paper also provided an example of how to use these dimensions in the process of designing a MOOC.

In a later study that focussed on the massive and open nature of courses, Pilli and Admiraal (2016) proposed a classification of MOOCs based across two dimensions: Massiveness and Openness; with four quadrants of representation:

- Small scale and less open, including courses with limited enrolments and a fee;

- Small scale and more open, including free courses with limited enrolment;

- Large scale and less open, including courses with some course material freely available, but restricted access to other material such as assessments;

- Large scale and more open, where content is freely available to all.

In a more recent analysis, Mohamed and Hammond (2017) examined ten MOOCs aimed at teachers of English as a Second Language. They considered three aspects: pedagogy, content, and 
assessment. All the MOOCs were studied from the learner perspective and all courses were instructor-led xMOOCs, with content mostly delivered by video, supplemented with other modes such as text. While all courses had some formative assessment with automated responses, only a smaller number delivered summative assessments.

The theoretical perspectives and the breadth of categorisations in the literature show that the majority of MOOC categorisations were created from the viewpoint of a MOOC provider or an academic; concentrating on issues such as the number of participants, the degree of openness and the approach to pedagogy.

\section{MOOC providers and aggregators}

Coursera, edX, and Udacity were the first major MOOC platform providers and all three are based in North America. Now almost a decade later, there are many new MOOC platform providers including several in Europe, for example, EMMA (European Multiple MOOC Aggregator) and FutureLearn. While the first MOOC platforms were all English language services, there are now MOOC platforms that are regional and/or cater for languages other than English, and include, Edraak (Arabic), MiriadaX (Spanish and Portuguese) and XuetangX (Chinese). Some governments have promoted national MOOC services, for example, France Université Numérique (FUN) platform which was launched by the French Ministry of Higher Education and Research, while the government of Mexico (through the Ministry of Education) funded MéxicoX, which is managed by the General Directorate of Educational Television.

This rapid increase in providers and expansion in the range of MOOC offerings has created a marketplace in which aggregator services add value by collecting MOOC offerings from various platforms and then reviewing and rating them independently of the individual providers (Bansal \& Kagemann, 2015). A MOOC aggregator is essentially a search engine that operates across the various MOOC providers and presents the information about these in a uniform manner for the convenience of potential learners.

\section{Methodology}

In the first step, the top four major MOOC providers and four most active aggregator services to be included in this study were identified. The four MOOC providers were identified (May 2017) from a list of all major providers on Class Central (https://www.class-central.com/providers).

Identifying the major MOOC aggregator sites was more challenging as a number of services had only existed for relatively short periods of time and some of these were no longer active. The first step in this process was to search for "MOOC aggregator sites" via google.co.nz. The first ten results were then analysed and services that were no longer live were removed. The remaining list of aggregators were visited and then evaluated based on the number of MOOCs listed and the current user interactions visible through comments and reviews on the site being studied. The four most active aggregator services were selected for further analysis. Subsequently, the list was verified against a search for "MOOC aggregator sites" on Google Scholar (https://scholar.google.co.nz). The top ten papers were searched to verify that the four selected MOOC aggregators were the main subjects of these papers. No additional live MOOC aggregators were found in any of these papers.

Each of the selected providers and aggregator services were initially allocated to one of the authors of this paper who conducted a free format review. In each case the reviewers were instructed to review from a state where they were not logged in to the platform and only accessing information available pre-registration to reflect the information available to a potential learner prior to registration. These reviews were then analysed to create a list of categories. 
The providers and aggregators were then re-allocated to a different author with the instruction to look at the first ten courses they could find from the home page of the provider or aggregator. They were then asked to check these against the original categories. Where there were discrepancies between the original categorisation and the new one, this was discussed by the authors to arrive at a final category. These categories where then compared and contrasted with the classifications from the literature review to produce a new taxonomy of MOOCs.

\section{Results}

\section{Investigation of four major MOOC providers}

An initial analysis was conducted for each of the four major MOOC providers identified by Class Central, based on the information provided to prospective learners before they are enrolled on a course. Usually this information is accessible via specific course pages, alongside other more generic information that is relevant to all courses from a particular provider. The following section describes the results of this investigation of the four major MOOC providers:

\section{Canvas Network}

Canvas Network (www.canvas.net) is a MOOC platform developed by the educational technology company Instructure and was launched in 2012. As of May 2017, it had over 200 institutions listed as partners.

At the top level there were only two categories available for filtering courses: "Educator Catalog" and "Girls in STEM", subsequently more categories became available.

\section{Information available on a course before joining}

This information is in varying formats across the courses offered, most course pages include:

- Course description and objectives;

- Educators;

- Course start date;

- Duration;

- Time commitment;

- Requirements (pre-requisites for the course);

- Course Type: may be instructor-led or self-paced;

- Credential: may be none, a certificate or a digital badge;

- Student ratings.

Some course pages are presented in other European languages including: French, Spanish, Dutch, Portuguese and Swedish.

\section{Coursera}

Coursera (www.coursera.org) is one of the pioneering MOOC platforms founded in 2012 by two Stanford University professors, Andrew Ng and Daphne Koller. Coursera has over 150 partners across 29 countries representing all continents offering 2,173 courses as of May 2017.

Courses are categorised into ten subject areas: Arts and Humanities; Business, Computer Science; Data Science; Life Sciences; Math and Logic; Personal Development; Physical Sciences and Engineering; Social Sciences; and Language Learning.

Some complementary courses are grouped together into a category called "Specialization" and more than 180 specializations are currently on offer with four full degree programmes. Courses 
are priced in the range $\$ 22-\$ 99$, while specializations are priced at around $\$ 39$ - $\$ 79$ per month. Online degrees are currently priced at $\$ 15,000-\$ 25,000$.

Courses that are offered in multiple languages use the descriptor category of "Course Languages" and those that have subtitles are listed under "Subtitle languages". For example, Arts and Humanities courses are offered in ten languages and subtitles for these courses are available in 24 languages. The number of languages courses are offered in, or subtitles supplied in, differs from category to category. From the current interface it is not easy to extract the total number of different languages courses are offered in.

\section{Information available on a course before joining}

- About this course: a short overview of the course;

- Who is this class for: including any pre-requisites;

- Created by: the institution offering the course;

- Level: beginner, intermediate (not specified in all courses);

- Taught by: the educators of the course and their title, role and affiliation;

- Commitment: time estimate per week (not specified in all courses);

- Language: Language of the course and if subtitles available, language of subtitles;

- How to pass: the criteria required to complete the course;

- User ratings: this provides a star rating (out of five stars) and a link to what participants (in previous offerings of the course) have said about the course;

- Syllabus;

- Start date;

- Hardware requirement (not specified in all courses).

$e d X$

edX (www.edx.org) was founded by Harvard University and MIT in 2012 and describes itself as an "online learning destination and MOOC provider". It had over 90 global partners as of May 2017 and claims to be the only leading MOOC provider that is both non-profit and open source. It uses the Open edX platform, a free and open source course management system.

It categorises courses into subject areas including: Architecture, Art \& Culture, Biology and Life Sciences, Business Management, Chemistry, Communication, Computer Science, Data Analysis and Statistics, Design, Economics and Finance, Education, Electronics, Energy and Earth Sciences, Engineering, Environmental Studies, Ethics, Food \& Nutrition, Health \& Safety, History, Humanities, Language, Law, Literature, Math, Medicine, Music, Philosophy \& Ethics, Physics, Science and Social Sciences. Its most popular subjects are in Computer Science, Business \& Management, Humanities, Language and Data Analysis \& Statistics

In addition to stand alone courses, it offers three programs:

- MicroMasters Certificate: comprising a series of Masters' level courses which are "crediteligible" and may be used to form a Masters' degree;

- Professional Certificate: a series of courses aimed at specialist training and professional education;

- XSeries Certificate: comprises courses aimed at providing a "deep understanding" of key subjects.

edX has the tag line "Free Online Courses. Advance your Career. Improve Your Life". The courses vary widely in length, from two weeks upwards. "Robotics Fundamentals" for instance is 12 weeks long, requiring 8-10 hours per week, and can be audited for free, or for a $\$ 349$ fee, a 
verified certificate can be obtained. In contrast, the "Introduction to Linear Models and Matrix Algebra" is spread over four weeks, with an expectation of 2-4 hours per week of learner effort. The certificate here costs $\$ 49$.

\section{Information available on a course before joining}

- Course overview;

- Instructors;

- Effort per week;

- Price;

- The institution in charge;

- Subject area;

- Level;

- Languages used.

Some of the courses embed other information, such as FAQs and reviews from external aggregators in the course overview, however these are not part of the categories provided by edX.

\section{FutureLearn}

FutureLearn (www.futurelearn.com) is a private company owned by the Open University and first offered courses in 2013. Partners in FutureLearn were originally a select group of UK universities, but now the partners have expanded to include international universities, as well as other cultural and educational institutions such as the British Library and the British Council.

FutureLearn identify a set of what they call "Categories" representing subject areas. Courses can be browsed within one of the 13 subject areas, though a course may be listed in multiple subject areas. Some complementary courses are grouped together into "Programmes" and a few courses contribute to degrees. Courses are only offered in the English language, with closed captions on videos to aid accessibility. Certification is available at a fee.

\section{Information available on a course before joining:}

- Fee: Courses have a free version where an enhanced version is available the fee is indicated. Recently a new model has been introduced where the participant pays to keep access to the course material;

- Overview: a brief description of the course, including: text and video, course length and hours per week;

- Topics: a bullet list of main topics, there is also information on the course objectives;

- Start dates/course length;

- Requirements (pre-requisites);

- Educators: the people fronting the course, there is also information on: Developers: often the University of the Educators; Supporters: details of any sponsors.

\section{Investigation of Four Major MOOC Aggregators}

\section{Class Central}

Class Central is a multiplatform register of MOOCs. Users can search MOOCs based on subjects and start date (including self-paced). They also include material on paid courses and "nanodegrees" which provide certificates for the learners. They also provide MOOC reports with trends and news. 
As of March 2018, there were 6292 listed upcoming or currently running courses and 2677 finished courses. 7214 courses have been assigned into 13 different subject categories, each with several sub-categories (from four to ten). Three of the main categories are from subjects related to computer science (Computer Science, Data Science and Programming), Three others are related to other sciences/engineering (Mathematics, Science and Engineering). Three are related to arts and human sciences (Humanities, Art \& Design, and Education \& Training). Two are related to social sciences (Social Sciences and Business) and there is a Health \& Medicine subject category.

Navigation to any of the subjects or starting date sections (e.g. recently started, just announced, courses in progress) takes the user to a list of courses.

Each course is displayed with:

- Title;

- Start date;

- University;

- MOOC platform;

- Rating: This is based on user comments and feedback within Class Central. MOOCs can pay to be listed at the top of the list, in which case they appear to be automatically rated with 5 stars.

Selecting a MOOC in the list takes the user to the individual page for the course.

Each course has:

- Title;

- Description: usually a copy of the course's description on the platform it was running;

- Class Central ranking by subjects;

- If the course is in the Top 50 courses this achievement it is displayed;

- Free/paid;

- Starting date / In progress;

- Subject;

- University;

- Platform;

- Language;

- Certificate available;

- Expected time per week;

- Length;

- User reviews. Each review includes: A star rating (out of 5 stars); User participation (completed, partially completed, taking the course now, dropped out, audited); User name/anonymous; Text; A usefulness score given by other reviewers/users.

There is also a list of related courses provided.

\section{CourseBuffet}

CourseBuffet (www.coursebuffet.com) has the tag line "The Most Organized Online Course Catalog". They have developed their own classification system, which they assign to every course in their catalogue. The CourseBuffet classification system is similar to that used by US universities, with an assignment to a subject area and a number indicating level: 
Table 1: The CourseBuffet classification system

\begin{tabular}{ll}
0 & no judgement level (for example public health) \\
$1-99$ & pre-university (college) level \\
$100-199$ & first year (Freshman) \\
$200-299$ & second year (Sophomore) \\
$300-399$ & third year (Junior) \\
$400-499$ & fourth year (Senior) \\
500 plus & post-graduate level (Graduate) \\
\hline
\end{tabular}

Similar courses are grouped in the same number (for example CS101 includes a number of distinct Introductory Computer Science courses). Additionally, tagging is used to help in identification of courses. Courses can be searched across 16 "areas" and each of these is subdivided into subjects, they can also be searched by the university offering the course and the MOOC provider.

Some of the data on CourseBuffet seemed to be out of date, with courses having start dates of 2015 listed as currently running, which ought to be listed as achieved.

Each course has:

- Title;

- Course details;

- Subject classification including indicated level;

- Provider;

- Availability (e.g. always available, finished/archive available, and archive may be available);

- Similar courses;

- Course reviews;

- Instructors;

- Institution;

- Language;

- Duration;

- Start date.

\section{Coursetalk}

Coursetalk (www.coursetalk.com) is a multiplatform aggregator of online courses, featuring MOOCs and other types of course (e.g. paid and small-scale courses). They have over 50,000 courses in their catalogue.

At the top layer the service shows "Featured courses". The user can search courses with keywords or click "New courses" and "Recommendations". Both new courses and recommendations are structured into areas of study (Arts \& Design, Business \& Management, Education, Humanities, Sciences \& Technology, and Sports \& Leisure). Recommendations are further structured into sub-categories (e.g. Art \& Design is sub-categorised into Design, Music, Performing Arts and Visual Arts). New courses are searchable by time to actual start (today, week, month) and whether it is a new course or an updated version of the course. 
Each course is displayed in the list with:

- Title;

- Review score (5 star) and number of reviews;

- Introduction;

- $\quad$ Cost (Free or fee for the course);

- Start date or "In session";

- Platform;

- Some courses are displayed with an example review.

Navigating to a MOOC in the list takes the user to the individual page for the course. Each individual course page has:

- Title;

- Review score (5 star) and number of reviews;

- Cost;

- Start date / end date;

- Key concepts;

- Description of platform;

- Course description (usually the same as platform's course description);

- User reviews. Each review includes:

- Name;

- A rating out of 5 stars;

- User participation (Completed, Taking Now, Dropped out);

- A usefulness score given by other reviewers/users.

\section{MOOC-List}

MOOC-List (www.mooc-list.com) is a multi-platform course aggregator. It offers multiple ways to search through the MOOC listing database that it has created. It is an "ads" intensive site. The opening splash page offers a search engine where the user can find MOOCs by multiple categories using the following search boxes:

- Course Title Contains;

- Course Category;

- Provider;

- University / Entity;

- Language;

- Sort by;

- Order.

In the footer of the splash there is also a series of links that offer pre-determined search profiles based on the following terms:

- $\quad$ Self-Paced MOOCs;

- MOOC List Coupon Discount;

- Providers and Categories;

- University / Entity;

- Instructor;

- Country; 
- Language;

- Type of Certificate;

- Tags (tags provide listing based on the tag e.g. Leadership).

The main body of the splash page showcases 20 short descriptions of courses that are available for study within the next 30-day time-period. This short-listing provides these details:

- Title;

- Start date;

- Tags for: Provider institution; Platform \& Language;

- Course overview (short abstract);

- Votes showing star rating (out of possible maximum of 10 stars) and number of votes;

- Subject tags.

Clicking on the course title directs to a more detailed single page course description with the following elements in the "main body" that are scraped from the course page on the provider site:

- Course title;

- Created by (university);

- Delivered by (MOOC provider platform);

- Instructors (Taught by);

- Description of the course comprising:

- Overview;

- Learning objectives / outcomes;

- Syllabus.

Navigating via the link "Go to class" takes the user directly to the course on the provider's site. In the right-hand column of the detailed page, described above, there are a series of hyperlinked course descriptors that detail:

- Cost to participate;

- Platform;

- Provider;

- Tutors;

- Area of study;

- Location;

- Level;

- Length of course;

- $\quad$ Effort expected (hours per week);

- Free Exam and/or Final Project;

- Verified Certificate (Paid) available;

- Cost of certificate;

- Language;

- Teaching method (e.g. video + discussion forum);

- Subject category tags;

- Rating. 


\section{Analysis}

\section{Analysis of MOOC Providers and Aggregators reviews}

Analysing the results of the reviews of MOOC providers and aggregators for common concepts 13 categories were identified as used to describe courses:

1. Brief description: a few lines summarising the course;

2. Syllabus;

3. Subject area: broadly the topic area or areas the course is in;

4. Educators: names and qualifications;

5. Institution: the name and country of the institution or institutions offering the course;

6. Supporter: any organisations supporting or sponsoring the course;

7. Provider: the platform on which the course is offered;

8. Timings: details of the dates and duration of the course, if it is offered in an asynchronous manner (self-paced), an indication of the time required each week or to complete the course;

9. Pre-requisites: any access to resources required, any prior study required, level of course;

10. Certification: details of any certification or credit that can be achieved by successful participation, maybe leading to a formal qualification;

11. Costs: details of any fees and free access;

12. Reviews: details of any reviews or rating from previous students or others;

13. Course languages: details of the language(s) used in the course, languages of any sub-titles. Table 2 summarises how each of the MOOC providers and aggregators reviewed match each category.

Table 2: Categories Emerging from terms used by MOOC Providers and Aggregators

\begin{tabular}{|c|c|c|c|c|c|c|c|c|c|}
\hline & Category & 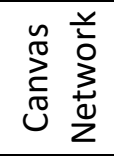 & 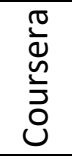 & 정 & 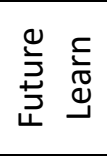 & 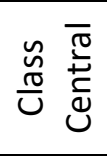 & 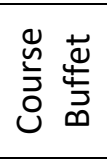 & 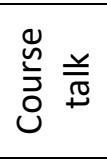 & 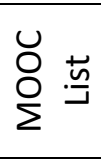 \\
\hline 1 & Brief description & V & V & V & v & v & V & V & V \\
\hline 2 & Syllabus & $x$ & V & $\mathrm{V}$ & V & $\mathrm{T}$ & $\mathrm{T}$ & $\mathrm{T}$ & $\mathrm{T}$ \\
\hline 3 & Subject area & $x$ & $\mathrm{~V}$ & V & V & V & V & V & 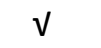 \\
\hline 4 & Educators & V & $\mathrm{V}$ & $\mathrm{V}$ & V & $x$ & $\sqrt{ }$ & V & $\sqrt{ }$ \\
\hline 5 & Institution & V & $\mathrm{V}$ & $\mathrm{V}$ & V & V & V & V & $\sqrt{ }$ \\
\hline 6 & Supporters & $x$ & $x$ & $\dagger$ & $\dagger$ & $x$ & $x$ & $x$ & $x$ \\
\hline 7 & Provider & $P$ & $\mathrm{P}$ & $\mathrm{P}$ & $P$ & 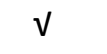 & 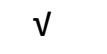 & $v$ & $\checkmark$ \\
\hline 8 & Timings & V & V & V & $\sqrt{ }$ & $\sqrt{ }$ & $\sqrt{ }$ & V & $\sqrt{ }$ \\
\hline 9 & Pre-requisites & V & $x$ & V & V & $X$ & $X$ & $X$ & $\dagger$ \\
\hline 10 & Certification & $\dagger$ & $\mathrm{V}$ & $\mathrm{V}$ & V & $\dagger$ & $x$ & $x$ & $\sqrt{ }$ \\
\hline 11 & Costs & $\dagger$ & $\mathrm{V}$ & $\mathrm{V}$ & V & $\dagger$ & $X$ & V & V \\
\hline 12 & Reviews & C & $\mathrm{V}$ & $X$ & $x$ & $\mathrm{~V}$ & V & V & V \\
\hline 13 & Course languages & $\dagger$ & V & V & $X$ & $\sqrt{ }$ & $\sqrt{ }$ & $X$ & $\sqrt{ }$ \\
\hline $\begin{array}{l}V-\ln \\
+-\ln \\
X-N \\
P-\text { Is } \\
\text { T-If } \\
\text { C-pr } \\
\text { Note: }\end{array}$ & $\begin{array}{l}\text { ated for all or most courses } \\
\text { ated where appropriate for a } \\
\text { ndicated (Never, rarely, or as } \\
\text { rovider } \\
\text { vided in the original text } \\
\text { ided by Class Central } \\
\text { urse Buffet's data seems to be }\end{array}$ & the manual & ourse d & escriptic & & & & & \\
\hline
\end{tabular}




\section{Discussion}

\section{Differences between MOOC providers and aggregators}

On analysing Table 2, there are some clear differences between providers and aggregators. Ratings and reviews are for instance key services on aggregators as they each have their own system providing this service. However, it is not common for providers to have this functionality. Only Coursera has its own system and Canvas Network has Class Central's ratings and reviews integrated into their course descriptions. It seems that aggregator sites differ from providers by primarily providing services for learners to establish the quality of courses from a variety of MOOC providers. In contrast to this the aggregators are prone to provide out-of-date information about courses, such as starting dates and costs.

Compared to aggregators, providers are giving information about the openness of courses (as pre-requisites) and certification information as these are important for providers, whereas such information is not prominent on aggregator services.

A reason for these differences might be that providers are keen to make it as easy as possible for learners to join the courses, whereas aggregators are helping learners to assess how useful the courses will be to them.

\section{Comparing with Literature}

\section{MOOC acronym}

The acronym MOOC stands for Massive Open Online Course. The majority of the categories identified from the reviews relate to the Course, while a small number can be mapped to Online and Open, none of the categories indicate Massive (Table 3).

Table 3: The MOOC acronym

\begin{tabular}{ll}
\hline Acronym & Emerging Categories \\
\hline Massive & None \\
Open & Pre-requisites, Costs, Course Language \\
Online & Provider, Timings \\
Course & All others \\
\hline
\end{tabular}

\section{xMOOCS/cMOOCs}

None of the emerging categories indicates the pedagogical or theoretical approach of the course, for example as a connectivist, collaborative or other type of online learning.

\section{Clark's taxonomy}

Three of Clark's taxonomy areas: Synch, Asynch and Mini can be mapped on to the category "Timings". His other taxonomy areas have no mapping to the emerging categories.

\section{Conole's classifications}

The degree of Openness in Conole's classification can include aspects such as: Pre-requisites, Costs, Course Language in the emerging categories. The classification Diversity in Conole's work may also embrace Course Language. The Certification classification can map on to the same named emerging category. None of the emerging categories indicate other information represented in Conole's classification. 


\section{Pilli and Admiraal's taxonomy}

Of the two proposed dimensions of the taxonomy Massiveness is not represented in the emerging categories, while Openness is captured in: Pre-requisites, Costs, Course Language.

\section{Mohamed and Hammond's Classification}

This study was undertaken from the perspective of learner's participating in MOOCs and there is no overlap with the emerging categories.

\section{A new classification}

The information available to potential learners prior to enrolment on a course was collected from the details published by MOOC providers and aggregators, and a number of categories emerged from reviewing this information.

Comparing these categories to the acronym "MOOC" revealed that none of the information provided to potential learners is indicative of anything to do with the Massive nature of the course, while the majority of these categories described aspects of the Course. Three categories: Pre-requisites, Costs, Course Language, referred to the Open nature and two categories: Provider, Timings, to the Online nature.

Comparing the emerging categories with classifications and taxonomies described in the literature (Clark, 2013; Conole, 2014; 2015; Daniel, 2012; Mohamed \& Hammond, 2017; Pilli \& Admiraal, 2016; Rodriguez, 2012) showed that there was limited overlap. The emerging categories largely describe the nature of the MOOC and how it will be delivered from the learner's perspective. In contrast, the existing classifications and taxonomies are oriented to the pedagogical nature of MOOCs primarily from the perspective of deliverers (educators, institutions and providers) and researchers examining MOOCs after they have run. Although, Mohamed and Hammond (2017) do consider the perspective of learners participating in MOOCs.

In summary, MOOC providers and aggregators provide information in a learner centric form, while existing MOOC taxonomies and classifications are oriented to academics, where the term academics embraces educators, institutions and researchers. Some of the existing MOOC taxonomies and classifications aim to capture the scale of participation in courses, but none of them consider aspects of completion or modes of participation although these topics are the subject of research. Perhaps this is a natural difference. Aggregators and providers are in the business of getting learners signing up, whereas the prior taxonomies are developed by academics.

A new taxonomy is needed that merges both the dimensions a learner is interested in when choosing a MOOC as well as the academic perspective. This is provided in Table 4, which uses the MOOC acronym as a starting point. Here each part of the acronym is extended with the categories and concepts from the literature and the categories found through the analysis conducted in this paper. 
Table 4: The New Taxonomy (* indicates it was found in this study)

\begin{tabular}{|c|c|c|c|}
\hline $\begin{array}{l}\text { Taxonomy } \\
\text { Term }\end{array}$ & Brief description & Example fields & References \\
\hline Massive & $\begin{array}{l}\text { A set of numeric data related } \\
\text { to the MOOC }\end{array}$ & $\begin{array}{l}\text { Enrolments } \\
\text { Retention } \\
\text { Engagement }\end{array}$ & $\begin{array}{l}\text { Conole, Pilli and Admiraal } \\
\text { Jordan } \\
\text { Ferguson and Clow }\end{array}$ \\
\hline Open & $\begin{array}{l}\text { Aspects that contribute to } \\
\text { the openness of the course }\end{array}$ & $\begin{array}{l}\text { Pre-requisites } \\
\text { Costs } \\
\text { Course Language } \\
\text { Aspects of diversity }\end{array}$ & $\begin{array}{l}* \\
* \\
\text { Conole }\end{array}$ \\
\hline Online & $\begin{array}{l}\text { Aspects relating to delivery } \\
\text { via the internet }\end{array}$ & $\begin{array}{l}\text { Platform used to } \\
\text { provide the course } \\
\text { Timing aspects } \\
\text { Use of multimedia } \\
\text { Accessibility } \\
\text { (diversity) }\end{array}$ & $\begin{array}{l}* \\
* \text {, Clark } \\
\text { Conole, Mohamed and } \\
\text { Hammond } \\
* \text {, Conole }\end{array}$ \\
\hline & $\begin{array}{l}\text { Aspects of course, including } \\
\text { areas listed to the left in } \\
\text { Italics: }\end{array}$ & & \\
\hline Assessment & & $\begin{array}{l}\text { Certification } \\
\text { Mode of assessment }\end{array}$ & $\begin{array}{l}* \text {, Conole } \\
\text { Mohamed and Hammond }\end{array}$ \\
\hline Pedagogy & & $\begin{array}{l}\text { Connectionist / } \\
\text { cMOOC } \\
\text { Instructor led / } \\
\text { xMOOC }\end{array}$ & $\begin{array}{l}\text { Rodriguez, Daniel, Clark, } \\
\text { Mohamed and Hammond } \\
\text { Rodriguez, Daniel, Clark, } \\
\text { Mohamed and Hammond, } \\
\text { Conole }\end{array}$ \\
\hline Quality & & $\begin{array}{l}\text { Quality Assurance } \\
\text { Reviews } \\
\text { Ratings }\end{array}$ & $\begin{array}{l}\text { Conole } \\
* \\
*\end{array}$ \\
\hline Delivery & & $\begin{array}{l}\text { Educators } \\
\text { Institution } \\
\text { Supporters }\end{array}$ & $\begin{array}{l}* \text {, Mohamed and Hammond } \\
* \\
*\end{array}$ \\
\hline Subject & & $\begin{array}{l}\text { Brief description } \\
\text { Syllabus } \\
\text { Subject area }\end{array}$ & $\begin{array}{l}* \\
* \\
*\end{array}$ \\
\hline
\end{tabular}

The taxonomy has been developed by assigning the various categories from the literature review and the aggregator service analysis to the various headers from the MOOC acronym. The course header has been subdivided into assessment, pedagogy, quality, delivery and subject to reflect that most categories were put under this heading.

By combining the academic perspective with the perspective of MOOC services this classification system unifies the perspectives and provides a better overview of how individual MOOCs fit with other MOOCs. It is a basis for both learners and academics to have a richer and more detailed understanding of an individual MOOC, which has been lacking in the previous classification literature through a more academic focus on analysing MOOC offerings.

\section{Conclusion}

This study started by comparing MOOC classifications found in the literature and they were found to primarily focus on the academic perspective of MOOCs. The information made 
available to prospective learners on MOOCs was the focus of this study and the four most popular MOOC providers and aggregator services where identified and reviewed. A total of 13 different categories were found that are commonly used to describe different MOOCs. They were: (a) brief description; (b) syllabus; (c) subject area; (d) educators; (e) institution; (f) supporter; (g) provider; (h) timings; (i) pre-requisites; (j) certification; (k) cost; (l) reviews; and (m) language.

It was found that there were some differences in focus between providers and aggregator services. For instance, aggregator services focus on ratings and reviews and provide prospective learners with tools to compare various MOOCs. In contrast, providers are more focused on the openness of each MOOC, for instance if there are pre-requisites and certificates available for the MOOC. Despite the emphasis on massiveness of MOOCs, this was not reflected in the course information made available by either providers or aggregators.

From the identified categories a new taxonomy of MOOCs is proposed; produced by comparing the identified categories to existing academic categorisations and merging them into a unified taxonomy using the MOOC acronym as a starting point. Most of the categories in the new taxonomy relate to the course aspects of a MOOC and this has been subdivided into: assessment, pedagogy, quality, delivery and subject. By developing these merged categories from the various studies, a taxonomy has been developed, which unifies academic views and information provided to prospective learners and therefore provides a more holistic categorisation of MOOCs.

The limitation of this study is that it concentrates on information provided to the learners in a selected set of platforms/aggregators in English medium and not the information the learners may wish that was available nor the individual learners' motivation for taking a course. Further studies are required of various learners' perspectives of the usefulness of information provided to them in selecting MOOCs; and if other information would have been helpful in decision making.

\section{References}

1. Bansal, S. K., \& Kagemann, S. (2015). Integrating big data: A semantic extract-transform-load framework. Computer, 48(3), 42-50. doi: 10.1109/MC.2015.76

2. Bozkurt, A., Keskin, N. O., \& de Waard, I. (2016). Research Trends in Massive Open Online Course (MOOC) Theses and Dissertations: Surfing the Tsunami Wave. Open Praxis, 8(3), 203-221. Retrieved from https://eric.ed.gov/?id=EJ1112556

3. Clark, D. (2013, April 16). MOOCs: taxonomy of 8 types of MOOC. Donald Clark Plan B [Blog post]. Retrieved from http://donaldclarkplanb.blogspot.co.uk/2013/04/moocstaxonomy-of-8-types-of-mooc.html

4. Conole, G. (2014). A new classification schema for MOOCs. The International Journal for Innovation and Quality in Learning, 2(3), 65-77. Retrieved from http://empower.eadtu.eu/images/fields-of-expertise/OERsMOOCs/INNOQUAL-Issue-3Publication-Sep-2014-FINAL-w-cover.pdf\#page $=72$

5. Conole, G. (2015). MOOCs as disruptive technologies: strategies for enhancing the learner experience and quality of MOOCs. Revista de Educación a Distancia, 39. Retrieved from http://www.um.es/ead/red/39/conole.pdf

6. Cormier, D. (2008, October 2). The CCK08 MOOC - Connectivism course, 1/4 Way. Dave's Educational Blog [Blog post]. Retrieved from http://davecormier.com/edblog/2008/10/02/the-cck08-mooc-connectivism-course-14way/

7. Daniel, J. (2012). Making sense of MOOCs: Musings in a maze of myth, paradox and possibility. Journal of interactive Media in education, 2012(3). http:/ /doi.org/10.5334/2012-18 
8. Downes, S. (2008). Places to go: Connectivism \& connective knowledge. Innovate: Journal of Online Education, 5(1), A6. Retrieved from https://nsuworks.nova.edu/innovate/vol5/iss1/6

9. Ebben, M., \& Murphy, J. S. (2014). Unpacking MOOC scholarly discourse: a review of nascent MOOC scholarship. Learning, Media and Technology, 39(3), 328-345. https://doi.org/10.1080/17439884.2013.878352

10. Ferguson, R., \& Clow, D. (2015). Examining engagement: analysing learner subpopulations in massive open online courses (MOOCs). Proceedings of the $5^{\text {th }}$ International Conference on Learning Analytics and Knowledge, 16-20 March 2015, Poughkeepsie, NY, USA, ACM, 51-58. http://dx.doi.org/doi:10.1145/2723576.2723606

11. Hollands, F. M., \& Tirthali, D. (2014). MOOCs: Expectations and Reality. Center for BenefitCost Studies of Education Teachers College, Columbia University. Retrieved from http:// files.eric.ed.gov/fulltext/ED547237.pdf

12. Jordan, K. (2014). Initial trends in enrolment and completion of massive open online courses. The International Review of Research in Open and Distributed Learning, 15(1). http://dx.doi.org/10.19173/irrodl.v15i1.1651

13. Jordan, K. (2015). MOOC Research Literature Browser. Retrieved from http://www.katyjordan.com/moocliterature

14. Liyanagunawardena, T. R., Adams, A. A., \& Williams, S. A. (2013). MOOCs: A systematic study of the published literature 2008-2012. The International Review of Research in Open and Distributed Learning, 14(3), 202-227.

15. Liyanagunawardena, T. R., Lundqvist, K. Ø., \& Williams, S. A. (2015a). Who are with us: MOOC learners on a FutureLearn course. British Journal of Educational Technology, 46(3), 557569.

16. Liyanagunawardena, T. R., Lundqvist, K. Ø., \& Williams, S. A. (2015b). Massive Open Online Courses and Economic Sustainability. European Journal of Open, Distance and e-Learning. 18(2). https://doi.org/10.1515/eurodl-2015-0015

17. Mohamed, M. H., \& Hammond, M. (2017). MOOCs: A Differentiation by Pedagogy, Content and Assessment. International Journal of Information and Learning Technology, 35(1). http://doi.org/10.1108/IJILT-07-2017-0062

18. Pilli, O., \& Admiraal, W. (2016). A taxonomy for Massive Open Online Courses. Contemporary Educational Technology, 7(3), 223-240. Retrieved from https://openaccess.leidenuniv.nl/bitstream/handle/1887/47088/Pilli_Admiraal2016.pdf

19. Rodriguez, C. O. (2012). MOOCs and the AI-Stanford like courses: Two successful and distinct course formats for massive open online courses. European Journal of Open, Distance and E-Learning, 15(2). Retrieved from http://www.eurodl.org/materials/contrib/2012/Rodriguez.pdf

20. Yuan, L., \& Powell, S. (2013). MOOCs and open education: Implications for higher education - A white paper: JISC CETIS. Retrieved from https://publications.cetis.org.uk/wpcontent/uploads/2013/03/MOOCs-and-Open-Education.pdf

\section{Acknowledgement}

Authors would like to thank Mr. Marios Konstantinidis and Ms. Sandra Scalzavara for their help with translating the article abstract. 